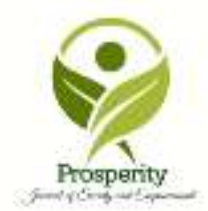

Prosperity: Journal of Society and Empowerment

Vol. 1 No. 1 (June 2021): 42-54

DOI: 10.21580/prosperity.2021.1.1.8139

\title{
India's Women Entrepreneurship Program Initiatives: Issues, Challenges and Opportunities
}

\author{
Mukta Goyal \\ Institute of Technology Delhi, India \\ e-mail: mgoyal1977@gmail.com
}

\begin{abstract}
The transformation of Indian society's social content, in terms of increased educational status for women and various ambitions for a better life, necessitated a change in the life style of Indian women. In every walk of life, she has competed with man and successfully stood up to him, and company is no exception. These female leaders are confident and willing to take risks. With their efforts, diligence, and perseverance, they were able to survive and succeed in this cutthroat rivalry. The aim of this paper is to investigate the main factors that encourage women to pursue entrepreneurial endeavors, as well as their role in growing women's entrepreneurial intentions in Indian micro, small, and medium businesses and the reasons for women's slow progress in India, suggestions for women's development, and schemes for promoting and developing women's entrepreneurship in India. The study discovers that antecedents such as motivational influences, perceived viability, and entrepreneurial ability play a significant role in the actions of women entrepreneurs. The results have been very significant in the few cases where training has been designed and delivered. This paper will discuss the current state of women entrepreneurs in India, as well as the obstacles and problems they face in establishing and managing their businesses in a highly competitive market. Primary sources, such as published studies, essays, and academic papers, are included in this paper's conceptual design.
\end{abstract}

Keywords: Entrepreneurship, Women, Business, Gender

\section{ABSTRAK}

Transformasi sosial masyarakat India dalam hal peningkatan status pendidikan bagi perempuan dan berbagai ambisi untuk kehidupan yang lebih baik, mengharuskan perubahan gaya hidup perempuan India. Dalam setiap aspek kehidupan, dapat dikatakan bahwa perempuan telah bersaing dengan pria hingga berhasil menghadapinya, pun dengan perusahaan. Para wanita ini percaya diri dan bersedia mengambil risiko. Dengan usaha dan ketekunan, mereka mampu bertahan dan berhasil dalam kompetisi yang sulit ini. Tujuan dari makalah ini 
adalah untuk menyelidiki faktor utama yang mendorong perempuan dalam mengejar usaha kewirausahaannya, serta peran mereka dalam menumbuhkan niat kewirausahaan di usaha mikro, kecil, dan menengah India. Selain itu, penelitian ini ingin mengetahui alasan lambatnya kemajuan perempuan di India, saran untuk pengembangan perempuan, dan skema untuk mempromosikan dan mengembangkan kewirausahaan perempuan di India. Studi ini menyatakan bahwa anteseden seperti pengaruh motivasi, kelayakan hidup yang dirasakan, dan kemampuan berwirausaha memainkan peran penting dalam tindakan perempuan berwirausaha. Hasilnya sangat signifikan. Hal ini berdasarkan eberapa kasus di mana pelatihan telah dirancang dan disampaikan. Selain itu, kurangnya pelatihan yang tersedia merugikan perempuan dan perusahaan mereka. Makalah ini akan membahas keadaan pengusaha perempuan di India saat ini, serta hambatan dan masalah yang mereka hadapi dalam membangun dan mengelola bisnis mereka di pasar yang sangat kompetitif. Sumber primer dalam penelitian ini seperti studi yang diterbitkan, esai, dan makalah akademis, terdapat dalam desain konseptual makalah ini.

Kata kunci: Kewirausahaan, Perempuan, Bisnis, Gender

\section{INTRODUCTION}

In simple terms, women entrepreneurs are powerful pillars that control 51 percent of an enterprise's resources and, in addition to owning capital, create 51 percent of job opportunities for women. Women who have earned an education are no longer bound by the four walls of their homes. They want their partners to regard them equally. However, since traditions are deeply rooted in Indian culture, where the sociological acknowledged has been a male dominated one, Indian women have had to go a long way to gain equal rights and positions. Women are seen as the weaker sex and are forced to depend on men in their families and in the community throughout their lives. Within the important family system, Indian culture made them only subordinates and executors of the alternatives made by other male members.

It is expected that women's economic empowerment will play a role in the country's growth, so the debate is crucial. Reformers, theorists, and social scientists consider women to be a major factor in national growth. India is a land of contradictions (Dey. A., et al, 2020). According to them (Pachorkar. et al, 2020), With the increase in literacy rate, urbanisation, education level, standard of living, and other factors, the society has embraced these changes positively in recent years, allowing women to actively participate and take a stand on an equal footing with men in almost every sphere. Women's empowerment and entrepreneurship have developed as a result of this. Women's empowerment and entrepreneurship have developed as a result of this. Women Entrepreneurship is described as any venture or organisation started by a woman or a group of women based on their thinking abilities, creative ideas, and attitude, and bringing these factors together to effectively and efficiently initiate, develop, coordinate, organise, guide, operate, and control the setup.

Women are worshipped as goddesses in Indian culture, as portrayed in the "Veda Puran." She is also revered as a money goddess. We must pay attention to the empowerment of rural women in India, especially in rural areas. Due to social norms, approximately 66 percent of the rural 
population of women are not productive. 90 percent of the total work force in agriculture and animal husbandry is made up of women. Women make up about half of the world's population, and they own about two-thirds of the world's land. They earn one-tenth of the world's total income, and they own less than one-hundredth of it. Females outnumber males by a factor of two out of every 900 million people on the planet. Women account for roughly $70 \%$ of those living in poverty. (Damor, V., 2020)

Rising women's educational attainment is critical to their empowerment. It has also been noted that some women are unable to function due to their physical limitations. They eat less, but they work harder. As a result, women who are weaker are to be made stronger from a health perspective. Another issue is female discrimination in the workplace. There have been several instances of rape, girl abduction, dowry abuse, and so on. As a result, they need all forms of empowerment in order to defend themselves and maintain their purity and dignity. (Chabra, S. dan Rao, N., 2020).

According to 2018 report, women account for $14 \%$ of the total entrepreneur base in the Indian economy. By the end of 2019, there had been a small increase of $20 \%$ in this figure. In this segment, however, the overall average rate of jobs was only 1.67 people per business enterprise. Many of the businesses were not owned by women entrepreneurs (T.N. Chhabra, 2019).

In 67 countries across the world, it was discovered that an estimated 126 million women were starting or managing new companies. In addition, 98 million people were believed to be in charge of existing enterprises. Men account for 52 percent of all entrepreneurial activity globally, with women accounting for the remaining 48 percent. Globally, the gender disparity in entrepreneurial practises varies. Women account for 1.5 to 45.4 percent of the adult population (Vijayaragavan, T., 2014). Growing industrialization and urbanisation, as well as innovative advances in the information technology (IT) field, have influenced women's career paths and professional roles in India. The government has also emphasised the need for women to receive specialised entrepreneurship training in order to start their own businesses. The Federation of Ladies Organisations (FLO), the Technology Development Board (TDB) of the Department of Science and Technology, the Entrepreneurship Development Institute of India (EDI), and the Federation of Indian Chambers of Commerce and Industry (FICCI) are among the organisations involved in this endeavour.

According to Parkas, Goyal (2011), the researcher's goal in their research was to figure out the reasons for women becoming successful business visionaries, such as training, financial backing, family and companion support, and so on. Despite this, they face numerous challenges such as domestic responsibilities, a lack of self-assurance, and a venerable and antiquated social perspective that prevents women from engaging in business activities. The government in the country has also floated plans for the growth and development of women's business enterprises. Many studies have attempted to provide a better understanding of the challenges faced by women when starting a company, according to (Hatammimi, J., \& Krisnawati, A., 2018).

Women empowerment, according to, is described as the creation of an atmosphere in which women can make autonomous decisions about their personal development while also shining as equals in society (Jainani, K., 2019). In low-income countries with a high birth rate, women are more likely to become entrepreneurs. 
These women are confident, persuasive, and willing to take chances. They were able to thrive and excel in this cutthroat rivalry due to their vigilance, diligence, and perseverance. Indian women entrepreneurs' strengths are their ability to quickly search out from her skills, their persuasiveness, transparent type of problem solving, willingness to take chances and opportunities, ability to inspire people, and knowing how to win and lose gracefully.

The challenges and opportunities presented to women in the digital age are expanding at such a rapid rate that job seekers are becoming job creators. Many women start businesses as a result of a traumatic event, such as divorce, pregnancy discrimination, or the corporate ceiling, a loved one's illness, or economic circumstances, such as a layoff. However, as more women choose to abandon the corporate world to chart their own destinies, a replacement talent pool of female entrepreneurs is emerging today. They're thriving as artists, interior decorators, exporters, publishers, and garment manufacturers, and they're always looking for new ways to make money.

\section{Concept of Women Entrepreneurs}

Women's entrepreneurship is thought to be essential in empowering women and improving their quality of life. Entrepreneurial operation begins on a personal level and can often be traced back to a single entity, the entrepreneur. As a result, an individual's attitudes or motives, talents, and psychological endowments all influence entrepreneurship. The gender gap in entrepreneurship is characterised as the difference in numbers of men and women engaged in entrepreneurial activity, motivations for starting a company, industry choice, business success, and development. The majority of entrepreneurship research on an individual level has concentrated on male entrepreneurial practises.

Female entrepreneurs are those who use their skills and expertise to grow or build new business opportunities, are actively involved in managing their companies, own at least 50\% of the company, and have been in business for at least a year (Norhalimah Idris and Joyce Tan, 2017).

If a woman is the "owner/proprietor/director of a private/proprietary business/private corporation" registered with the "joint stock" or "shareholding enterprise," owning at least 51 percent annual turnover and share among the shareholders, and creates job opportunities for others by administering the enterprise, she is considered an entrepreneur (Mathew, R. V., \& Panchanatham, N., 2011).

One of the most important factors contributing to the growth of society is entrepreneurship. In a gender-focused global entrepreneurship survey released in July 2013 by PC maker Dell and Washington-based consulting firm Global Entrepreneurship and Development Institute (GEDI) India was ranked among the worst performing countries in the field of women entrepreneurship. India is ranked 16th out of 17 nations, just ahead of Uganda. Turkey, Morocco, and Egypt have all outperformed India. In India, women's access to higher education is lower than in the majority of other nations. Women's entrepreneurial roles in large-scale industries and technology-based companies are currently small. Women's involvement in small-scale manufacturing, however, is extremely poor. According to the third all-India census of small-scale industries, women owned just 10.11 percent of micro and small businesses, and only 9.46 percent of them were run by women. While the number of women running their own businesses is growing around the world, they continue to face significant barriers to their development, such as a lack of resources, strict social 
constraints, and limited time and ability. India was ranked 70th out of 77 countries in a survey conducted by the Global Entrepreneurship and Development Institute (GEDI). India received a score of 25.3 in this study's Female Entrepreneurship Index, indicating that substantial improvements are needed to remove barriers for female entrepreneurs in India. This study also discovered that women entrepreneurs in India were motivated by opportunity rather than need (Kumar, P., 2015). According to the BNP Paribas Global Entrepreneurialism Report, India has the highest percentage of active female entrepreneurs. In India, nearly half of all active entrepreneurs are women (49 percent). The micro sector accounts for the bulk of these companies (BNP Paribas 2015).

\section{Reasons for Women Becoming Entrepreneurs}

Since Industry 4.0 is affecting almost every industry, entrepreneurs should thoroughly plan their companies, including their financial aspects. Glass ceilings have been broken, and women now work in almost every industry. In India, women's forays into business can be traced back to their kitchen activities, especially the 3Ps, Pickle, Powder, and Pappad. Women became aware of their ability to grow entrepreneurial skills as the socio-cultural climate changed and educational opportunities increased. These socio-cultural shifts, as well as the eagerness of a variety of non-governmental organisations (NGOs) to collaborate with female entrepreneurs, have all contributed to the rise of female entrepreneurship in recent decades. Even though gender equality and equal opportunity are constitutional rights in India, men and women still have different standards of behaviour, including in the workplace. Female work outside the home is regarded as mildly inappropriate, subtly incorrect, and certainly dangerous to chastity and womanly virtue in rural areas (Vijayakumar, A. and Jayachitra S., 2013). Female entrepreneurship is a relatively new phenomenon in India as a result of these social expectations and beliefs.

However, as education spread and time passed, women began to transition from the 3Ps to the modern 3Es, i.e., Energy, Electronics, and Engineering. Girls join business projects for a variety of reasons, including abilities, experience, and adaptability. A woman entrepreneur may also be someone who takes on a difficult job in order to meet her personal needs and become financially self-sufficient. Entrepreneurial women have a deep desire to do something good, and they are capable of contributing ideals in both family and social life.

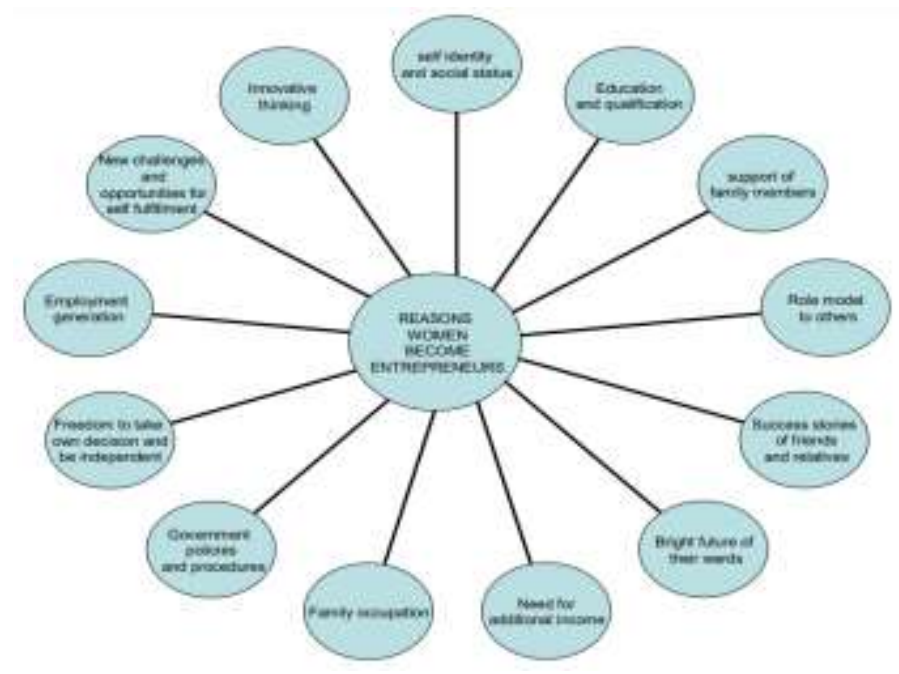

Source: insightssikhiri.wordpress.com 
Importance of Women Entrepreneurship in Digital Era

It is important for the economy's growth to increase the number of women who are selfemployed. The following illustration demonstrates this. (1) Amount 343 million of the country's 432 million working-age women are not compensated for any structured jobs. (2) Women's participation in the workforce in India is among the lowest in the world, and it is continuing to decline. (3) Increased female entrepreneurship will increase women's retention in the workforce, as they will not be forced to leave their jobs due to digitization and automation. (4) It will change the Indian SME industry by increasing women's participation in the workforce, resulting in more job opportunities and industry growth. Up to 170 million people will be employed if women's entrepreneurship grows.

\section{Reasons for The Slow Development of Women Entrepreneurs in India}

Female entrepreneurship has been stifled due to the problems and limitations that they face (Sumana, M., 2013). The following are the most popular roadblocks faced by female entrepreneurs: (1) The fact that they are women is the most basic deterrent for female entrepreneurs. The foundation of their path to business success is a patriarchal-male dominant social order. Financing women's projects is seen as a major risk by male members. (2) Male chauvinism still exists in many areas of the world. Women are regarded as abla, or frail, in all respects. Women are not regarded as competent men in a male-dominated society, which acts as an obstacle to women entering the workforce. (3) Male entrepreneurs, who are easily interested in promotion and growth and conduct simple marketing of their goods with both the coordinated sector and their male counterparts, compete fiercely with women entrepreneurs. As a result of such a rivalry, women entrepreneurs are ultimately liquidated. (4) Women's lack of self-confidence, willpower, a positive mental outlook, and an ambitious mindset generates a fear of making mistakes when performing their duties, which relationships and thus society are reluctant to face alongside their entrepreneurial development. (5) In India, women are well-protected. They are not less educated, insecure economically, or selfdestructive. The old and obsolete social outlook that prohibits women from joining the field of entrepreneurship is one of the reasons for his or her failure. They are subjected to social constraints that hinder their ability to thrive and succeed in the field of entrepreneurship. (6) Women's mobility in India is severely restricted, compared to men's, for a variety of reasons. One of the women who had requested a room was suspicious. The challenging process of starting a company, which includes officials' demeaning attitudes toward women, forces them to abandon their entrepreneurial spirit. (7) In both developed and developing countries, women's family commitments discourage them from becoming effective entrepreneurs. Female entrepreneurs are discouraged by financial institutions because they believe they will ultimately abandon their companies and return to being housewives. (8) Family bonds and relationships are more important to Indian women than they are to men. Women who are married must strike a delicate balance between work and family obligations. The partnerships that are extended to women in the business process and management are often critical to the success of a business. Family and personal responsibilities can be a major roadblock to a good business career for women. Only a select few women are capable of running both their homes 
and their businesses. (9) Women's family and personal responsibilities can be a major roadblock to a good business career. Just a few women are equipped to effectively run both their homes and their businesses, allocating sufficient time to prioritise all of their responsibilities. (10) Women's presence in the business world is often influenced by their husbands' educational level and family history. (11) Many of the women who enrol in the Entrepreneurial Development programme do not have a business mentality. Tests, interviews, and other methods must be used to assess the aptitude of women who obtain instruction from different institutions. (12) Some company activities have a high expense, which has a negative effect on the success of female entrepreneurs. Female entrepreneurs are discouraged from venturing into new areas by the installation of new machinery during the expansion of productive capacity, as well as other similar factors. (13) Women's businesses are often small, and it's not always easy for girls to get the information they need about technology, training, creative schemes and concessions, alternative markets, and so on. Just a small number of female entrepreneurs use technology, and they are often restricted to using computer software. Advanced applications such as SAP mathematical software, TALLY accounting software, 3D MAX animation software, the internet, and other similar programmes are seldom used. (14) Lack of understanding of financial assistance offered by financial institutions in the form of grants, loans, and schemes, among other things. As a result, genuine attempts to help women entrepreneurs in rural and underserved areas will fall short. (15) The achievement motivation of female members was found to be lower than that of male members. When it comes to interacting in company activities and running a business, poor women with low levels of education and trust have lower levels of achievement and advancement motivation.

Aside from the issues mentioned above, women entrepreneurs may face a variety of other significant issues, such as insufficient infrastructure, high production costs, societal attitudes toward women's modern business outlook, and low enterprise needs. Women start their own businesses ten years later than men on average. A late start in entrepreneurial careers has been attributed to a variety of factors, including motherhood, a lack of managerial experience, and conventional socialisation.

\section{Challenges and Problems Faced by Women Entrepreneurs}

It is much more difficult for women to advance in business and achieve great success than it is for men. Along the way, they encounter a variety of issues, including. (1) The fact that they are females living in a male-dominated society where males are often given preference over female species, especially in company, is the biggest roadblock in their way. Financial institutions are more critical of women entrepreneurs and their ability to manage their businesses, making it more difficult for women to obtain funding for their businesses. Women also lack the ability to provide tangible protection because they rarely own significant assets in their own names, such as homes. (2) In a country like India, a lot of focus is put on how the rest of the world perceives us, and in certain parts of the country, things like women going to work and running a company are frowned upon. Women are taught from birth to depend on their male family members, resulting in a lack of faith in their own abilities. They lack trust in their ability to handle business duties because they have been taught that such work is only for men and that it is too difficult for them. Their involvement in business is often influenced by their husband's educational background and family 
background. There are few institutions that provide women assistance and training in entrepreneurship. Lack of knowledge about financial and government programmes aimed at assisting women entrepreneurs in their growth. Women who want to start their own company are often demotivated by cultural limitations and a lack of role models. Many women find it difficult to keep up with the rapid speed of digitization while still caring for children and becoming the families second breadwinner. (3) All of them are afraid of taking risks and are ignorant. Women's mobility in the country is still restricted. It is still difficult for a single woman to request a bed. Women's development is often hampered by sexism. Women are more likely to work in managerial positions, which are being increasingly digitised. Indian women place a higher value on their family bonds and responsibilities, prioritising them over their jobs, causing them to lose focus on increasing their businesses. Women's literacy levels are found to be lower than men's, affecting their ability to respond to changes and new technologies.

\section{Opportunities and Advantages for Women in Entrepreneurship}

\section{A Diverse and Innovative Workforce}

Sex, community, age, and race diversity encourages innovation and creativity. Top businesses all over the world strive to prioritise and reap the benefits of a diverse and creative workforce. Men and women from various backgrounds carry with them a variety of experiences that form their approach to business. They will work creatively and move the business forward by challenging and engaging with one another.

\section{Strength in Soft Skills and Emotional Intelligence is an Advantage for Women}

Technical knowledge and skills are needed for success. Soft skills and emotional intelligence, on the other hand, are crucial. Self-awareness, empathy, and the capacity to listen are all examples of emotional intelligence in leadership. While difficult to quantify, these characteristics can have a significant impact. Women can effectively lead their businesses by combining their backgrounds, soft ability aptitude, and emotional intelligence.

\section{Ability to Create a Woman-friendly Corporate Environment}

Many corporations' corporate cultures may be hostile to women. When a woman runs her own company, however, she has the power to create an atmosphere that is welcoming to other female employees. A woman who is an entrepreneur will live a more honest life and build a corporate culture that is more aligned with her own values.

\section{METHODS}

This paper is a nature descriptive study. Primary sources, such as published studies, essays, and academic papers, are included in this paper's conceptual design. The challenges faced by women entrepreneurs were highlighted in this study, especially in this digital age. It also highlighted the challenges that women have encountered on their path to entrepreneurship success.

Objectives of the study (1) To study the complications encountered by women entrepreneurs. (2) To find out the successful women entrepreneurs in India. (3) To assess the factors that encourage women to become entrepreneurs. (4) Research the impact of government 
assistance on women's entrepreneurship. (5) To conduct a critical examination of the issues confronting female entrepreneurs.

\section{RESULTS AND DISCUSSION}

\subsection{Steps Taken by The Government}

Since its inception, the government has prioritised the production of girls as a policy priority. Prior to the 1970s, women's advancement was largely concerned with healthcare. In the 1970s, there was a change from a welfare approach to a development approach, which understood the development method's mutually reinforcing essence. In the 1980s, a multidisciplinary approach was taken, with three main areas of focus: health, education, and jobs. Women were given first priority in all fields, including SSI. Government and nongovernmental organisations have paid more attention to women's economic contributions through self-employment and industrial projects.

The establishment of the Central Social Welfare Board, the formation of Mahila Mandals, and the introduction of Community Development Programmes were all moves in the right direction in the First Five-Year Plan (1951-56) for women's welfare.

In the second Five-Year Plan, women's empowerment was closely related to the overall strategy of intensive agricultural growth programmes (1956-61).

In the Third and Fourth Five-Year Plans (1961-66 and 1969-74) respectively, female education was promoted as a major welfare measure.

Women who required income and security were given priority in the Fifth Five-Year Plan (1974-1979). This strategy was timed to correspond with the International Women's Decade and the submission of India's report to the Committee on the Status of Women. In 1976, the Women's Welfare and Development Bureau was created by the Ministry of Social Welfare.

During the Sixth Five-Year Plan (1980-85), a strong change away from welfare and toward growth was visible. It described a critical impediment to women's growth as their lack of access to capital.

The Seventh Five-Year Plan stressed the importance of gender equity and empowerment (1985-1990). For the first time, quality aspects such as instilling trust, raising knowledge of rights, and offering training in skills for better jobs were prioritised.

The Eighth Five-Year Plan (1992-97) centred on empowering women, especially at the Gross Roots Level, through Panchayati Raj Insights.

\subsection{Organizations}

The Women's Component Plan policy was introduced in the Ninth Five-Year Plan (19972002), with at least $30 \%$ of funds/benefits earmarked for women-related sectors.

The Tenth Five-Year Plan (2002-07) aims to empower women by putting the National Policy for Women's Empowerment (2001) into action and ensuring the survival, safety, and advancement of women and children through a rights-based approach.

Currently, the Indian government runs over 27 women's schemes across different departments and ministries. There are some of them: Integrated Rural Development Programme (IRDP), Khadi And Village Industries Commission (KVIC), Training of Rural Youth for Self-Employment 
(TRYSEM), Working Women's Forum, Indira Mahila Yojana, Indira Mahila Kendra, Mahila Samiti Yojana, Mahila Vikas Nidhi, Prime Minister's Rojgar Yojana (PMRY), Entrepreneurial Development programme (EDPs), Management Development progammes Women's Development Corporations (WDCs), Marketing of Non-Farm Products of Rural Women (MAHIMA), Assistance to Rural women in Non-Farm Development (ARWIND) schemes, Trade Related Entrepreneurship Assistance and Development (TREAD), SBI's Stree Shakti Scheme, NGO's Credit Schemes, Micro \& Small Enterprises Cluster Development Programmes (MSE-CDP), National Banks for Agriculture and Rural Development's Schemes, Rajiv Gandhi Mahila Vikas Pariyojana (RGMVP), Priyadarshini Project- A programme for $=$ Rural Women Empowerment and Livelihood in Mid Gangetic Plains', NABARDSEWA Bank project, Exhibitions for women, under promotional package for Micro \& Small enterprises approved by CCEA under marketing support, Micro Credit Scheme, Rashtriya Mahila Kosh, SIDBI's Mahila Udyam Nidhi, Mahila Vikas Nidhi, SBI's Stree Shakti Scheme, NGO's Credit Schemes, Micro \& Small Enterprises Cluster Development Programmes (MSE-CDP), National Banks for Agriculture and Rural Development's Schemes, Rajiv Gandhi Mahila Vikas Pariyojana (RGMVP), Priyadarshini Project- A programme for Rural Women Empowerment and Livelihood in Mid Gangetic Plains', NABARD-SEWA Bank project, Exhibitions for women, under promotional package for Micro \& Small enterprises approved by CCEA under marketing support.

Non-governmental organisations (NGOs), which play an equally important role in promoting women's empowerment, complement the efforts of the state and its various agencies. Despite governments' and non-governmental organisations' best efforts, there are several differences. In reality, we've come a long way in terms of women's empowerment, but the long road ahead remains challenging and demanding.

\subsection{Suggestion for Changing Challenges Into Potential Opportunities}

Women entrepreneurs and their increased involvement in entrepreneurial activities necessitate concerted efforts from all sectors. Female entrepreneurs must cultivate trust, freedom, and versatility in order to break free from their paradoxes, and entrepreneurship ultimately means being in charge of one's life and activities (Deshpande, S., \& Sethi, S., 2009).

The following steps are recommended to help women in business take advantage of different opportunities and overcome obstacles. (1) Female entrepreneurs should be inspired, encouraged, motivated, and collaborated with on a regular basis. (2) The aim of a large-scale awareness campaign should be to raise women's awareness of the various dangers they face. places to do business. (3) To enhance women's overall personality standards, efforts should be made to improve their educational standards in general, as well as to make appropriate arrangements for their instruction, practical experience, and personality development programmes. (4) Plan training programmes to assist workers in gaining technical skills in fields such as management, leadership, marketing, finance, production, benefit planning, bookkeeping, and other areas. More women may be encouraged to start their own businesses as a result of this. (5) Women in the group receive vocational training to learn about the assembly process and production management. (6) Exciting opportunities for professional growth In training-cum-production workshops, women's polytechnics and industrial training institutes were exhausted, and skills were put to use. (7) To support entrepreneurship growth, 
educational institutions should collaborate with various government and non-government organisations, especially in the planning of business projects. (8) Women should be able to network with other female entrepreneurs through international, national, and local trade fairs, industrial exhibitions, workshops, and conferences. (9) Low-interest loans and subsidies for women in industry should be made available to enable them to pursue industrial endeavours. Small and large-scale projects should receive more funding support from financial institutions. (10) At the local level, providing microsystems and business systems to female entrepreneurs. (11) Various government schemes and incentives designed to grow entrepreneurs in the state could help the poorer sections raise funds. For example, the Rozgar Yojana of the Prime Minister, the Khadi and Rural Village Industries Scheme, and so on. (12) Women entrepreneurs may face difficulties in the early stages of their businesses, but they must persevere, believe in themselves, and refuse to give up. (13) Various non-governmental organisations (NGOs) and government organisations have attempted to disseminate information about policies, plans, and strategies for women's development in business, trade, and commerce. Female entrepreneurs must take advantage of government programmes. (14) Women should prepare to update themselves in the changing times by using the latest technical advancements. In order to gain skills and expertise in all functional areas of business, including management, women must be educated and trained on a regular basis. This could help women succeed in the hiring process and establish a reliable business network. (15) Self-help organisations of female entrepreneurs may play a constructive role in addressing this issue by mobilising resources and pooling capital funds, among other things, to assist women in the industries of manufacturing, trade, and commerce. (16) To fully comprehend the distinctions between men's and women's entrepreneurship, women's entrepreneurship must be analysed at both the individual and organisational levels (i.e. the decision to become self-employed) as well as at the company level (the success of women owned and run firms). (17) To create all-India forums for discussing problems, concerns, issues, and filing complaints about constraints or deficiencies in the economic progress path of women entrepreneurs, and to make appropriate decisions in their favour, as well as to take a firm stand against policies or strategies that hinder such a group's economic development path. Women's problems are often resolved by enacting the aforementioned legislation in letter and spirit. Women's entrepreneurship is not without its challenges. Women engage in a number of economic activities to augment their family's income; their involvement has no effect on their earnings.

\section{CONCLUSION}

A path to becoming an entrepreneur is fraught with difficulties, particularly for women, especially in India, because our society, rather than empowering and encouraging women, ridicules and discourages them at every point. Today, however, women are embracing and overcoming all obstacles in order to prove themselves at every turn, and they are beginning to work toward their goals. Today, many women begin their careers as entrepreneurs and inspire other women, serving as role models for potential generations of female entrepreneurs.

Women make significant contributions to the nation's economic growth. Despite many hurdles in their way, women are steadily pursuing their own business ventures with creative 
goods and services that are beneficial to society as a whole. Many people used to think that women started businesses because of external causes such as poverty, need, or the death of their husbands, but nowadays, women start businesses because of internal motivators such as new ideas, innovation, and the desire to take risks. In 2016, the government launched Startup India, a programme that encourages women to start businesses and promotes entrepreneurship in India. Although the government has aided women entrepreneurs in some ways, knowledge and encouragement are needed for women to achieve their full potential.

Women's involvement in the field of entrepreneurship is growing at a substantial pace, and it is often claimed that we are now in a better position. In the economy, efforts are being made to ensure that Indian women have equal opportunities in all fields, and laws ensuring equal participation in the political process, as well as equal opportunities and rights in education and jobs, have been implemented. Unfortunately, only a small group of girls, namely

urban bourgeoisie women, have benefited from government-sponsored development activities. Nearly half of India's population is made up of women. Effective steps must be taken now to provide entrepreneur women with orientation and skill development services. Female entrepreneurs' role in economic growth is also being recognised, and steps are being taken to encourage female entrepreneurship. Entrepreneurship revival is the need of the hour, with a focus on educating the female population, spreading knowledge and consciousness among women to help them shine in the enterprise sector, allowing them to recognise their strengths and important role in society, and thus the significant contribution they can make to their industry and the overall economy. Women entrepreneurs must be better moulded with entrepreneurial traits and expertise to meet the changes. Trends, global economies, and even the ability to maintain and aspire for success in the entrepreneurial arena are all important factors to consider. Women's status in India has been changing since the beginning of the twenty-first century as a result of increasing industrialization and urbanisation, as well as sporadic mobility and social legislation. Over time, an increasing number of women have pursued higher education, technical and professional education, and their share of the workforce has risen as well. Women have moved from kitchens, handicrafts, and conventional cottage industries to non-traditional higher levels of activities as knowledge and understanding have spread. The government has also placed a strong focus on the need for women to receive specialised entrepreneurship training in order to start their own businesses. Financial institutions and banks have also set up special cell to assist women entrepreneurs.

\section{REFERENCES}

Chabra, S., Raghunathan, R., \& Rao, N. V. M. (2020). Investigating the Role of Motivation in Strengthening Entrepreneurial Intention Among Women Entrepreneurs in India. Enhancing Future Skills and Entrepreneurship, 281.

Damor, V. K. (2020). Initiative for Women Empowerment in India. International Journal of Reviews and Research in Social Sciences, 8(1), 08-10.

Deshpande, S., \& Sethi, S. (2009). Women entrepreneurship in India. International Research Journal, 2(9), 13-17. 
Dey. A., Patel, S., \& Rashid, M. M. (2020). Small-scale Mushroom Production Unit for the Upliftment of Rural Economy and Women Empowerment in India: A Review. Current Journal of Applied Science and Technology, 38-46.

T.N. Chhabra (2019) Entrepreneurship development "women entrepreneurs" page number from 3.1 to 3.13 .

Goyal, M., \& Parkash, J. (2011). Women entrepreneurship in India-problems and prospects. International journal of multidisciplinary research, 1(5), 195-207.

Hatammimi, J., \& Krisnawati, A. (2018, September). Financial literacy for entrepreneur in the industry 4.0 era: A conceptual framework in Indonesia. In Proceedings of the 2018 10th International Conference on Information Management and Engineering (pp. 183-187).

Jainani, K. (2019). Visionary Entrepreneurship in India in the Digital Era: A Predicated Factors-Based Study. IUP Journal of Entrepreneurship Development, 16(2).

Kumar, P. (2015). A study on women entrepreneurs in India. International Journal of Applied Science \& Technology Research Excellence, 5(5), 43-46.

Mathew, R. V., \& Panchanatham, N. (2011). An exploratory study on the work-life balance of women entrepreneurs in South India. Asian academy of management journal, 16(2).

Norhalimah Idris and Joyce Tan(2017) Review of Literature on Women Entrenpreneurs, Journal of Global Business and Social Entrepreneurship (GBSE) Vol. 1: no. 3 (2017) page 1-11/ gbse.com.my / eISSN 24621714.

Pachorkar, S., Kawishwar, S., \& Sharda, P. (2020). WOMEN ENTREPRENEURSHIP AND WOMEN EMPOWERMENT IN INDIA: A CASE STUDY OF JWALA MAHILA SAMITI. Prestige International Journal of Management and Research, 12(1/2), 254-264.

Smith-Hunter, A. (2006). Women Entrepreneurs Across Racial Lines: Issues of Human Capital, Financial Capital and Network Structures, Edward Elgar Publishing.

Sumana, M. Women Entrepreneurs in India: Need, Scope, Functions, Qualities and Role M.B. Murthy and M. Naga Gopinath (2013), Imagination and Visualization Two Essentials for Women Entrepreneurship and Empowerment, https://www.ripublication.com/gjmbs_spl/gjmbsv3n6_02.pdf, Global Journal of Management and Business Studies. ISSN 2248-9878 Volume 3, Number 6 (2013), pp. 573-580.

Vijayaragavan, T. (2014). Problems and Opportunities of Women Entrepreneurs in India. International Journal of Business and Management Invention, 3 (7), 59-61.

Vijayakumar, A and Jayachitra S. (2013). Women entrepreneurs of India - emerging issues and challenges. International Journal of Women Development research 04, 012 - 017. 